\title{
Editorial
}

\section{Stability and Seakeeping of Marine Vessels}

\author{
Ermina Begovic ${ }^{1, *(1)}$ and Simone Mancini ${ }^{2}$ (i) \\ 1 Department of Industrial Engineering, Università Degli Studi di Napoli Federico II, 80138 Naples, Italy \\ 2 Department of Hydro and Aerodynamics, Force Technology, 2800 Kgs. Lyngby, Denmark; simo@force.dk \\ * Correspondence: begovic@unina.it
}

Citation: Begovic, E.; Mancini, S. Stability and Seakeeping of Marine Vessels. J. Mar. Sci. Eng. 2021, 9, 222. https://doi.org/10.3390/jmse9020222

Received: 16 February 2021

Accepted: 16 February 2021

Published: 19 February 2021

Publisher's Note: MDPI stays neutral with regard to jurisdictional claims in published maps and institutional affiliations.

Copyright: (c) 2021 by the authors. Licensee MDPI, Basel, Switzerland. This article is an open access article distributed under the terms and conditions of the Creative Commons Attribution (CC BY) license (https:// creativecommons.org/licenses/by/ $4.0 /)$.
Stability has always been the main safety issue for all marine vessels, and static stability evaluation is adequate for ship service. Recently, research interests have focused on ship dynamics and stability failure modes in rough seas for higher safety. Hence, seakeeping assessment today is one of the most important design features to establish operational limits for both speed and comfort.

The book Stability and Seakeeping of Marine Vessels includes nine contributions [1-9] to this Special Issue published during 2020. The overall aim of the collection is to improve knowledge about the most relevant and recent topics in ship stability and seakeeping. Specifically, the articles cover a wide range of topics regarding ship stability and seakeeping and reflect the recent scientific efforts in second-generation intact stability criteria evaluation and modelling of ship dynamics assessment in intact or damaged conditions. These topics are investigated mainly through direct assessments performed both via numerical methods and tools, such as boundary element methods (BEM) and computational fluid dynamics (CFD), and via EFD (experimental fluid dynamics). A brief overview of all the contributions, emphasizing the main investigation topic and the outcomes of the analysis, follows.

Zhang et al. (2019) [1] focus on the analysis of the effect of damage openings, specifically side and bottom damage openings, on the ship flooding process. The investigation is carried out numerically using the commercial CFD code CD Adapco Star CCM+, and the damaged hull investigated is the DTMB 5415 ship at zero speed. The URANS (Unsteady Reynolds average Navier-Stokes) simulation results indicate that the flooding process and the hull motion responses are strongly sensitive to the damaged opening positions and the internal compartment arrangement. Furthermore, the visualization of the flooding process efficiently explains the causes of the motion responses and can improve the analysis of ship survivability.

Mei et al. (2020) [2] propose an improved potential flow model for the hydrodynamic analysis of ships advancing in waves. This advanced potential flow method is based on the desingularized Rankine panel method, which is improved with the added effect of nonlinear steady wave-making (NSWM) flow in the frequency domain. The method is validated with results of simple geometry and a modified Wigley hull. A comparison of the results indicates that the improved model using the NSWM flow can give results in better agreement with the experimental results than those obtained using different potential flow approaches.

Pennino et al. (2020) [3] investigate a new adaptive weather routing model based on the Dijkstra shortest path algorithm with the aim of selecting the optimal route that maximizes the ship performances in a seaway. The model is based on a set of ship motionlimiting criteria and the weather forecast maps, providing the sea state conditions that the ship is expected to encounter along the scheduled route. The new adaptive weather routing model is applied to optimize the scheduled route of a containership in the northern Atlantic Ocean. The results show that it is possible to achieve appreciable improvements, up to $50 \%$ of the ship seakeeping performances, without excessively increasing the route length and the voyage duration.

Begovic et al. (2020) [4] present an experimental validation of the hybrid frequencytime domain method for vertical motions assessment for the hard-chine "low-drag" dis- 
placement hull. Currently, for a warped hard-chine hull operating in displacement and semi-displacement regimes, there is no adequate numerical tool available. Thorough validation of the applied method is performed in irregular head and following seas at Froude numbers $F r=0.2,0.4$, and 0.6. Simulations are performed with the time step equal to the frequency of sampling, and an identical analysis of the numerical and experimental time series is performed, giving reliable results in head and following waves.

Petacco and Gualeni (2020) [5] give an overview of the development process that leads to the finalized version of second-generation intact stability criteria (SGIS), providing for each of the five stability failure modes a brief description of the vulnerability level requirements. Operational measures, categorized into two typologies-operational guidance and operational limitations-are analyzed through the application for a Ro-Ro Pax Ferry ship and finally provide guidance and limitations during navigation.

Ljulj and Slapnicar (2020) [6] present full-scale seakeeping tests conducted on a coastal patrol ship (CPS) during ship trials. Coast guards around the world have numerous challenges related to peacetime tasks, such as preventing human and drug tracking, fighting terrorism, controlling immigration, and protecting the marine environment, and, therefore, excellent seakeeping is of paramount importance. All relevant seakeeping criteria in different sea states are analyzed, including CPS behavior at high speed in severe sea states as well as the stern vertical displacement at the low speed required for launch and recovery tasks. The authors report a comparison of measured motions on sea against numerical calculations and model tests, and they review the set of seakeeping criteria to be used at the design stage.

Jing et al. (2020) [7] perform a study on the optimization of the motion response in waves of a barge platform using a zero-pressurized air cushion incorporated into the barge platform. The pressure of the zero-pressurized air cushion is equal to atmospheric pressure. Compared to the conventional pressurized air cushion, the zero-pressurized one has the advantage of less air leakage risk. The numerical results, based on the boundary element method, show that in regular and irregular waves, the air cushion could significantly reduce the amplitude of motions response close to the resonance condition.

Martic et al. (2020) [8] study the effect of ship characteristics on added resistance in regular waves and irregular head sea in relation to the IMO (International Maritime Organization) goal of reducing $\mathrm{CO}_{2}$ emission by ships. Hydrodynamic calculations of added resistance of the KCS (Kriso container ship) are performed by the 3D panel method based on potential flow theory. The obtained numerical results are corrected for the direction component of added resistance in short waves and validated against the experimental data available in the literature. Numerical uncertainty is evaluated for the results in regular waves, whereas monotonic convergence is achieved and for the mean value of added resistance in irregular waves for certain sea states. The obtained results provide an overview of the effect ship characteristics variation on added resistance.

Finally, Pacuraru et al. (2020) [9] carry out a fully numerical analysis of the seakeeping performance of the KCS vessel. Several hydrodynamic methods, in-house code based on linear strip theory, the 3D fully nonlinear time-domain boundary element method (BEM), and the commercial CFD code NUMECA are employed to obtain accurate results of ship hydrodynamic response in regular head waves. The results obtained using these methods are presented and discussed to establish a methodology for estimating the ship response in regular waves with accurate results and to determine the sensitivity of hydrodynamical models.

Author Contributions: Conceptualization, E.B. and S.M.; resources, E.B. and S.M.; writing-original draft preparation, E.B. and S.M.; writing-review and editing, E.B. and S.M.; supervision, E.B. All authors have read and agreed to the published version of the manuscript.

Funding: This research received no external funding.

Conflicts of Interest: The authors declare no conflict of interest. 


\section{References}

1. Zhang, X.; Lin, Z.; Mancini, S.; Li, P.; Liu, D.; Liu, F.; Pang, Z. Numerical Investigation into the Effect of Damage Openings on Ship Hydrodynamics by the Overset Mesh Technique. J. Mar. Sci. Eng. 2020, 8, 11. [CrossRef]

2. Mei, T.; Candries, M.; Lataire, E.; Zou, Z. Numerical Study on Hydrodynamics of Ships with Forward Speed Based on Nonlinear Steady Wave. J. Mar. Sci. Eng. 2020, 8, 106. [CrossRef]

3. Pennino, S.; Gaglione, S.; Innac, A.; Piscopo, V.; Scamardella, A. Development of a New Ship Adaptive Weather Routing Model Based on Seakeeping Analysis and Optimization. J. Mar. Sci. Eng. 2020, 8, 270. [CrossRef]

4. Begovic, E.; Bertorello, C.; Cakici, F.; Kahramanoglu, E.; Rinauro, B. Vertical Motions Prediction in Irregular Waves Using a Time Domain Approach for Hard Chine Displacement Hull. J. Mar. Sci. Eng. 2020, 8, 337. [CrossRef]

5. Petacco, N.; Gualeni, P. IMO Second Generation Intact Stability Criteria: General Overview and Focus on Operational Measures. J. Mar. Sci. Eng. 2020, 8, 494. [CrossRef]

6. Ljulj, A.; Slapničar, V. Seakeeping Performance of a New Coastal Patrol Ship for the Croatian Navy. J. Mar. Sci. Eng. 2020, 8, 518. [CrossRef]

7. Jing, F.; Xu, L.; Guo, Z.; Liu, H. A Theoretical Study on the Hydrodynamics of a Zero-Pressurized Air-Cushion-Assisted Barge Platform. J. Mar. Sci. Eng. 2020, 8, 664. [CrossRef]

8. Martić, I.; Degiuli, N.; Farkas, A.; Gospić, I. Evaluation of the Effect of Container Ship Characteristics on Added Resistance in Waves. J. Mar. Sci. Eng. 2020, 8, 696. [CrossRef]

9. Pacuraru, F.; Domnisoru, L.; Pacuraru, S. On the Comparative Seakeeping Analysis of the Full Scale KCS by Several Hydrodynamic Approaches. J. Mar. Sci. Eng. 2020, 8, 962. [CrossRef] 